\title{
Inflation and Economic Growth: Evidence from the Southern African Development Community*
}

\author{
Manoel Bittencourt ${ }^{\dagger} \quad$ Reneé van Eyden ${ }^{\ddagger} \quad$ Monaheng Seleteng ${ }^{\S}$
}

December 23, 2014

\begin{abstract}
In this paper we investigate the role of inflation rates in determining economic growth in fifteen sub-Saharan African countries, which are all members of the Southern African Development Community (SADC), between 1980 and 2009. The results, based on panel time-series data and analysis (we use the Fixed Effects and Fixed Effects with Instrumental Variables estimators to account for heterogeneity and endogeneity in thin panels), suggest that inflation has had a detrimental effect to growth in the community. We highlight that inflation has offset the Mundell-Tobin effect and consequently reduced the much needed economic activity in the community, and also the importance of an institutional framework conducive to a stable macroeconomic environment as a precondition for development and prosperity in the community.
\end{abstract}

Keywords: Inflation, Growth, SADC.

JEL Classification: E31, O11, O42, O55.

${ }^{*}$ We thank the Editor of the Journal, Alain Kabundi, Stephen Miller, an ERSA referee and seminar participants at Pretoria, ESSA 2011 in Stellenbosch and ERSA Financial Economics Workshop in Cape Town for comments. Financial support from ERSA is acknowledged.

${ }^{\dagger}$ Department of Economics, University of Pretoria, Lynnwood Road, Pretoria 0002, South Africa, Email: manoel.bittencourt@up.ac.za.

${ }^{\ddagger}$ Department of Economics, University of Pretoria, Lynnwood Road, Pretoria 0002, South Africa, Email: renee.vaneyden@up.ac.za.

$\S^{\S}$ Department of Economics, University of Pretoria, Lynnwood Road, Pretoria 0002, South Africa and Research Department, Central Bank of Lesotho, Maseru 100, Lesotho, E-mail: mseleteng@centralbank.org.ls. 


\section{Introduction}

The African continent is known for its recent political independence from European rule (mostly in the 1960s), for political regime changes during the cold war (with some countries sidelining with the former Soviet Union and others with the United States, Berger, Corvalan, Easterly and Satyanath 2013), for civil and military conflict (which tends to be associated with the importance of natural resources, Besley and Persson 2008), and for poor macroeconomic performance (in terms of economic activity and prosperity the late 1980s and early 1990s saw even negative growth rates in some countries). More recently though, the continent saw some economic structural adjustments and reforms taking place, not to mention political stability, that have generally been matched by better economic performance overall, Pinkovskiy and Sala-i-Martin (2014).

Taking the above background into account, we investigate the role of inflation rates in determining economic growth in the Southern African Development Community (SADC). This community of countries includes the likes of, eg Angola and Mozambique with positive growth rates since the 1990s and even with some double figures from 2004 onwards, Botswana and Mauritius with positive growth since the 1980s, South Africa with positive growth, although modest, since the end of the Apartheid regime in 1994 and a country like Zimbabwe which has presented negative growth rates since 1999. Specifically, we use data from all these fifteen SADC countries between 1980 and 2009 and panel time-series analysis (we allow for country and time fixed effects to account for heterogeneity and structural changes, and also make use of instrumental variables in order to deal with reverse causality in thin panels) to study whether inflation played any role in generating growth and prosperity in the community.

Interestingly enough, although these SADC countries differ in terms of economic and institutional development, eg with Botswana, Mauritius and South Africa being more developed than most of the other countries in the community, they also share common factors and goals, ie most of them went through particular economic and political structural changes from the 1960s onwards. Therefore, we pay special attention to these fifteen countries which are part of a community that professes the importance of "regional integration, peace and security, democracy and development" as tools to 
eradicate poverty in the community.

Firstly, one would argue that some inflation can be conducive to growth by the Mundell-Tobin effect and its predicted shift from money holdings to financial assets that usually drive real interest rates down and which might lead to an increase in economic activity. In other words, with permanent higher inflation people tend to convert their real money balances into financial assets (or savings), which reduce real interest rates and that can have a positive effect on growth. Secondly, others would argue that inflation can be detrimental to growth because it might increase macroeconomic uncertainty, which usually leads to lower investment, and consequently lower economic activity as well. All in all, the link between inflation and growth is not at all obvious and therefore deserves attention.

In addition, the importance of acquiring a better understanding of the role of inflation on growth is because recently there has been a protracted hyperinflationary event in Zimbabwe with all its detrimental consequences to economic activity and also because there is an ongoing debate in countries like South Africa about the role, legitimacy and efficacy of independent central banks in conducting monetary policy. There is also a related debate on whether the South African Reserve Bank should aim at low interest rates until unemployment rates reach a particular level. Therefore, it is important to better understand the causes and also the consequences of macroeconomic management to economic activity.

The empirical results suggest that inflation has been a robust macroeconomic determinant of growth in the community and also that its effect has been a negative one on growth, offsetting the Mundell-Tobin effect. It is therefore fair to say that the lack of certain economic institutions (de jure and de facto central-bank independence and a credible fiscal authority, Acemoglu, Johnson, Querubín and Robinson 2008), combined with political instability, facilitated the process of generating easy money which some would argue to be a device used by governments which are losing control of their own finances to fund themselves, Fischer (1993). The process of generating easy money leads to higher inflation rates, with all their consequences on macroeconomic uncertainty, economic activity, growth and welfare in general.

The literature on inflation and growth has a long and enduring tradition in Economics. Firstly, De Gregorio (1993) and Bittencourt (2012) present 
evidence using different panels of Latin American countries in the post-war period to suggest that inflation is detrimental to economic growth (or that economic agents in general shift to activities which are "not the engines of sustained growth"). Moreover, Fischer (1993) presents international crosssectional and panel data evidence for the period 1961-1988 to suggest that inflation outweighs the Mundell-Tobin effect, or that inflation reduces the capital stock in the economy by increased macroeconomic uncertainty.

Furthermore, Barro (1995, 1998 and 2013) makes use of international data covering the period 1960-1990 and cross-sectional analysis to suggest that the high-inflation countries in his sample drive the negative effects of inflation on growth, or that "households are thought to perform poorly when inflation is high". In addition, Bullard and Keating (1995) make use of annual time-series data and VAR analysis to reach a similar conclusion, ie that in the high-inflation country in their sample, inflation negatively affects growth, or that the Mundell-Tobin effect is offset by the macroeconomic uncertainty coming from inflation.

Moreover, Clark (1997) uses a panel of eighty five countries between 1960 and 1985 to confirm the above, ie that economic agents "devote productive resources to dealing with inflation". Furthermore, Bruno and Easterly (1998) suggest that there is no long-run relationship between inflation and growth in cross-sectional analysis. Nevertheless, they suggest, using a nonparametric approach and data covering the period 1961-1994, that there is a negative relationship between inflation and growth when inflation reaches their proposed $40 \%$ threshold.

Following from the latter, Sarel (1996), Gosh and Phillips (1998), Khan and Senhadji (2001) and Seleteng, Bittencourt and van Eyden (2013) confirm, with different samples of countries, the above negative relationship between inflation and growth once inflation reaches particular thresholds. Moreover, Sirimaneetham and Temple (2009) make use of an index for macroeconomic instability and Bayesian Model Averaging to suggest that macroeconomic stability is a necessary condition for economic growth in a panel of 70 developing countries during the period 1970-1999. In contrast, Bullard and Keating (1995) and Rapach (2003) present some evidence that the Mundell-Tobin effect is valid in samples of industrialised countries which have also presented very low inflation in the post-war period.

In essence, most of this (non-exhaustive) literature review suggests that 
high, or higher, inflation is detrimental to growth in large cross-sectional, time-series, panel and panel time-series data samples. It outweighs the Mundell-Tobin effect by creating particular distortions, including increased macroeconomic uncertainty, which result in a shift to less productive activities and consequently reduced growth rates. However, there is also some evidence suggesting that the Mundell-Tobin effect is valid in industrialised countries with low inflation. Needless to say that in a continent like Africawhich suffers from relative poverty, delayed industrialisation and which has experienced episodes of high inflation in the past-understanding what is the sign of this causality is important for overall economic welfare.

Hence, it is fair to say that this paper is a natural development of the previous literature on the subject. We conduct a case study - as suggested by Fischer (1993) — of an important community of African countries that attempts to pinpoint, given the different possible directions of causality, the effects of macroeconomic performance on economic activity. We do that by avoiding the averaging, which can masquerade the detrimental effects of inflation, by making use of annual data, Bruno and Easterly (1998), and also by taking advantage of panel time-series analysis, in an attempt to better capture the role of inflation on growth. Therefore, we are able to provideto the best of our knowledge, for the first time - informative estimates which suggest that the Mundell-Tobin effect is outweighed in a community of countries which displays diverse performance in terms of inflation rates, eg with Botswana presenting single digits for most of the period and the Democratic Republic of the Congo with double digits for the whole period, so that our knowledge of a very idiosyncratic, and also diverse within, southern Africa is furthered.

\section{Empirical Analysis}

\subsection{A Look at the Data}

The dataset used covers the period between 1980 and 2009, and fifteen sub-Saharan African countries which are all members of the SADC, namely Angola, Botswana, the Democratic Republic of the Congo, Lesotho, Madagascar, Mozambique, Mauritius, Malawi, Namibia, South Africa, Swaziland, Seychelles, Tanzania, Zambia and Zimbabwe $(T=30$ and $N=15)$. To illustrate the importance of these countries in the regional context, these fifteen 
countries accounted for approximately $52 \%$ of the total GDP in sub-Saharan Africa in 2009.

The growth rates of the real gross domestic products per capita (GROW) are taken from the World Bank's World Development Indicators and the data on inflation rates (INFLAT), with its usual log transformation $\ln (1+$ INFLAT/100), Fischer (2005), come from the same source and also from the International Monetary Fund's World Economic Outlook (IMF WEO). Although the Mundell-Tobin effect is a theoretical possibility, given most of the empirical literature, it is fair to expect a negative relationship between inflation and growth in the community, ie higher inflation might lead to an increase in macroeconomic uncertainty, which in turn becomes detrimental to economic activity, Fischer (1993).

The control variables used are standard in the literature and we follow Durlauf, Johnson and Temple (2005) extensive chapter in the Handbook of Economic Growth where they list different groups of variables that, in one way or another, have already been regressed against growth, which include proxies for inflation, investment, education, government, trade openness, financial development and democracy. Given data availability, we attempt to represent all these groups, without unnecessary duplications or omissions, in our empirical specifications later on in the analysis.

Firstly, we include the ratio of the gross fixed capital formation to GDP $(I N V)$ from the World Bank, a canonical Solow growth determinant, and it is expected that investment positively affects growth, Bond, Leblebicioğlu and Schiantarelli (2010). Furthermore, we include a variable accounting for the role of education, $(E D U C)$, which is defined as the number of teachers per 100 pupils in secondary education and this proxy for education is provided by the World Bank as well. In this case we expect a positive effect of education on growth, Mankiw, Romer and Weil (1992).

In addition, we include a proxy for government, the ratio of final government consumption expenditure to GDP $(G O V)$, which comes from the World Bank and IMF files. It is predicted that high government consumption tends to be detrimental to growth, Barro (1991). Moreover, we include a measure of trade openness, $(O P E N)$, which comes from the World Bank files as well. It is expected that more open societies, in terms of trade, tend to grow faster, Wacziarg and Welch (2008).

We also use a baseline measure of financial development, the ratio of the 
liquid liabilities to GDP (M2), from the World Bank and it is expected that wider access to finance increases economic activity, Levine (2005). Finally, we account for democracy and institutional quality by using the normalised, so that it ranges from zero to one, polity2 variable $(P O L)$ from the Polity IV database. It is predicted that more democratic societies tend to grow faster, Papaioannou and Siourounis (2008).

To illustrate, Figure One depicts the averaged-data on log inflation and GDP per capita growth rates in all fifteen countries in the sample, and what we can see is that the 1980s saw stable inflation and some economic growth. Moreover, in the 1990s inflation saw a considerable increase which was matched by a decrease in growth rates ${ }^{1}$. Coincidentally enough, growth rates became positive again once inflation was brought under control towards the end of the 1990s.

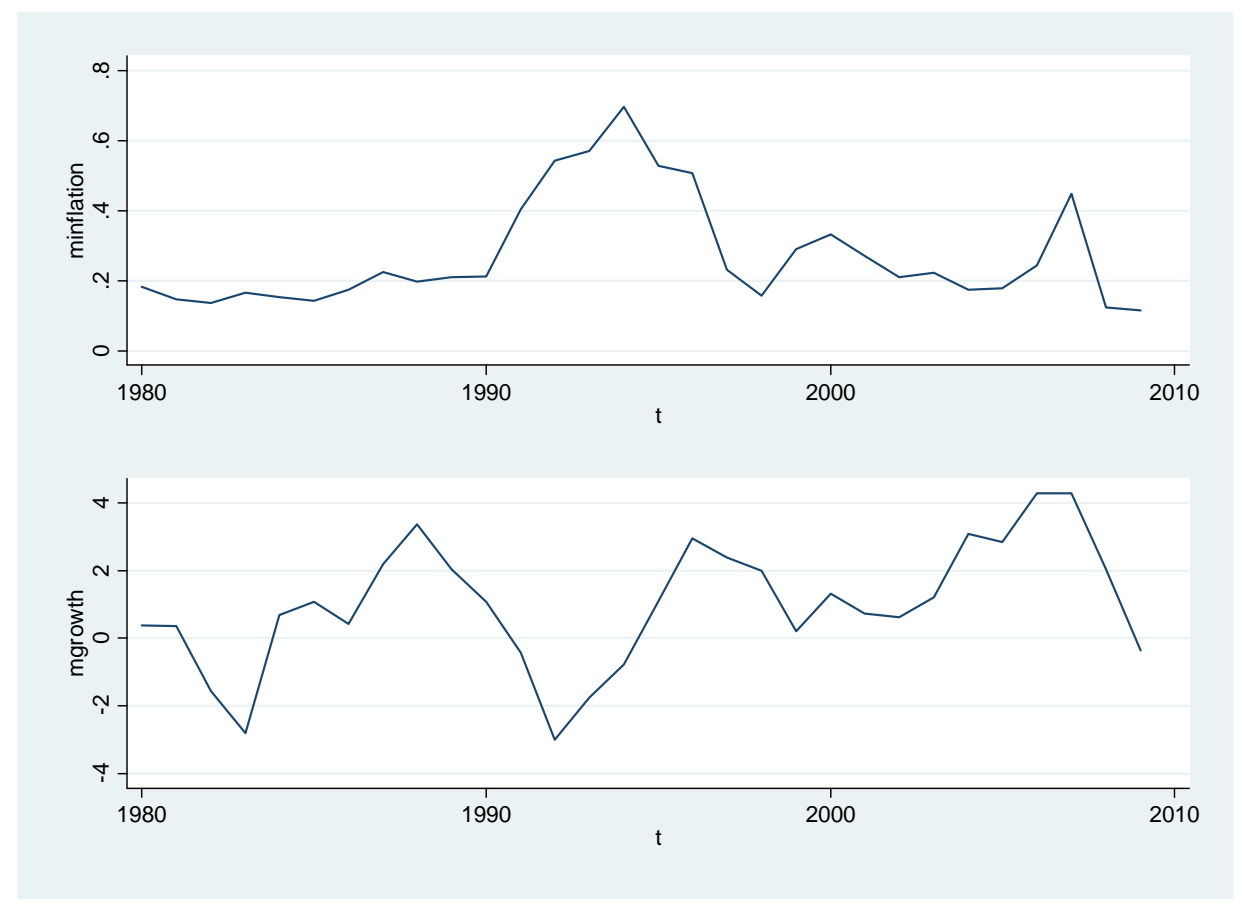

Figure 1: Inflation and GDP per capita growth rates, SADC, 1980-2009. Sources: World Bank and IMF.

Moreover, Table One presents the descriptive statistics of the variables

\footnotetext{
${ }^{1}$ It is perhaps worth mentioning that those high inflation rates in the 1990s do not include the Zimbabwean hyperinflation which starts more towards the end of the 1990s.
} 
(in levels) in the first panel and then the correlation matrix of the variables in logs in the second panel. It is worth mentioning that, in terms of growth rates, Angola presents the lowest rate in the sample (-27 percent in 1993) and the highest rate as well (17 percent in 2005). In terms of inflation, Madagascar presents the lowest rate in the sample (-1.22 percent in 2003) and Zimbabwe the highest (24,411 percent in 2007).

About the correlations, inflation and growth present a negative and statistically significant correlation to each other, Fischer (1993). The control variables present, for most of the time, the expected signs, ie investment is positively correlated to growth, Bond, Leblebicioğlu and Schiantarelli (2010), as well as trade openness, Wacziarg and Welch (2008) and democracy, Papaioannou and Siourounis (2008).

Education is positively correlated to economic growth, however, not statistically significant and the measure of financial development is also positively correlated to growth, however not significant either. Lastly, government consumption presents a positive and significant correlation to economic activity, which goes against the prediction that governments tend to be detrimental to economic activity, Barro (1991). 
Table 1: Descriptive Statistics and the Correlation Matrix: SADC, 1980-2009.

\begin{tabular}{|c|c|c|c|c|c|c|c|c|}
\hline Variables & Obs & Mean & Std Dev & Min & $\operatorname{Max}$ & \multicolumn{3}{|c|}{ Source } \\
\hline GROW & 433 & 1.02 & 5.30 & -27.22 & 17.11 & \multicolumn{3}{|c|}{ WDI } \\
\hline INFLAT & 448 & 177.05 & 1640.57 & -1.22 & 24,411 & \multicolumn{3}{|c|}{ WDI and WEO } \\
\hline INV & 450 & 20.91 & 10.46 & 2.06 & 76.69 & \multicolumn{3}{|c|}{ WDI } \\
\hline EDUC & 450 & 5.01 & 1.17 & 2.64 & 7.96 & \multicolumn{3}{|c|}{ WDI } \\
\hline GOV & 450 & 19.85 & 9.48 & 2.12 & 55.39 & \multicolumn{3}{|c|}{ WDI and WEO } \\
\hline OPEN & 450 & 89.90 & 44.60 & 14.32 & 255.01 & \multicolumn{3}{|c|}{ WDI } \\
\hline M2 & 405 & 32.53 & 21.14 & .461 & 120.46 & \multicolumn{3}{|c|}{ WDI } \\
\hline POL & 450 & 1.21 & 7.01 & -10 & 10 & \multicolumn{3}{|c|}{ Polity IV } \\
\hline & GROW & INFLAT & INV & EDUC & GOV & OPEN & M2 & POL \\
\hline GROW & 1 & & & & & & & \\
\hline INFLAT & $-0.32^{*}$ & 1 & & & & & & \\
\hline INV & $0.33^{*}$ & $-0.35^{*}$ & 1 & & & & & \\
\hline EDUC & 0.05 & 0.02 & $0.14^{*}$ & 1 & & & & \\
\hline GOV & $0.13^{*}$ & $-0.14^{*}$ & $0.40^{*}$ & $0.24^{*}$ & 1 & & & \\
\hline OPEN & $0.26^{*}$ & $-0.10^{*}$ & $0.47^{*}$ & $0.45^{*}$ & $0.49^{*}$ & 1 & & \\
\hline M2 & 0.08 & $-0.33^{*}$ & $0.34^{*}$ & 0.02 & $0.33^{*}$ & $0.37^{*}$ & 1 & \\
\hline POL & $0.20^{*}$ & -0.09 & $0.24^{*}$ & $0.17^{*}$ & 0.06 & $0.21^{*}$ & $0.32 *$ & 1 \\
\hline
\end{tabular}

Sources: World Bank, IMF and Polity IV. * represents significance at the $5 \%$ level.

Furthermore, Figure Two depicts the OLS regression line between log inflation and per capita growth in all fifteen SADC countries (we use the country averages), and the relationship is negative and statistically significant, which suggests that there is an economic relationship between these two variables in the panel, or that the Mundell-Tobin effect was outweighed by the increased macroeconomic uncertainty caused by inflation in these SADC countries, which resulted in lower growth rates overall. 


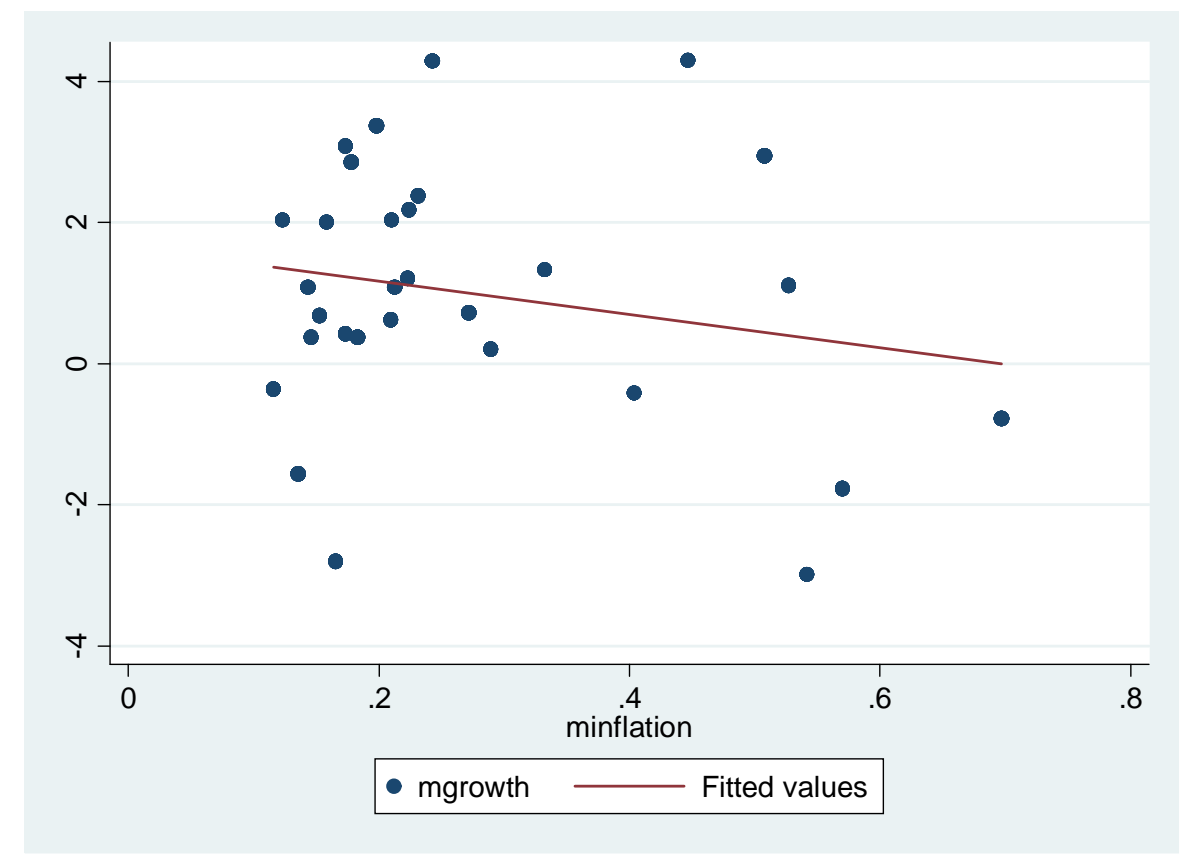

Figure 2: OLS Regression Line, Inflation and GDP per capita growth rates, SADC, 1980-2009. Sources: World Bank and IMF.

\subsection{Empirical Strategy}

Since we have a $T>N$ data set $(T=30$ and $N=15)$, the empirical strategy used is based on panel time-series analysis. Panel time-series allows us to deal with important econometric issues in relatively thin panelsheterogeneity and endogeneity biases - and also to specifically further our knowledge of sub-Saharan Africa without having to incur in the removal of African countries from large cross-sectional or panel data analyses. With panel time-series we can specifically analyse the SADC case, with all its idiosyncrasies and differences within, without treating it either as an outlier or as a dummy, and therefore we can get a clearer picture of the community.

Firstly, although some of the variables are either ratios or indices and therefore bounded within closed intervals, we evoke Phillips and Moon (1999) and their result which suggests that the issue of spurious regressions is less of a problem in panels because of the averaging taking place in panel estimators, which reduces the prospective noise.

Secondly, the issue of statistical endogeneity, which arises because the 
unobserved individual effects that are nested in the error term might be correlated to the regressors, and heterogeneity of intercepts are dealt with by the one- and two-way Fixed Effects (FE) with robust standard errors estimator. The FE estimator provides consistent estimates in dynamic models when $T \rightarrow \infty$, Smith and Fuertes (2010).

In addition, Judson and Owen (1999) argue that the issue of the Nickell bias in dynamic $T>N$ panels - of order $O(1 / T)$, and which is caused because the FE transformed error term which purges the country-specific effect tends to be correlated with the lagged dependent variable - can be a problem even with $T=30$. Therefore, we implement the bias approximation provided by Bruno (2005) which extends on Bun and Kiviet (2003) and which allows for an unbalanced panel to give "corrected" FE estimates. In this case, given the nature of the dataset, we use the Anderson and Hsiao option as the baseline consistent estimator.

Essentially, although these countries shared some political and economic transitions in their recent history, the FE estimator accounts for important econometric issues in dynamic $T>N$ panels, statistical endogeneity and heterogeneity biases, or for the fact that some of these countries do indeed present different levels of economic development, eg South Africa is known to be relatively more developed than most countries in the community, and also for particular changes that happened during the period investigated here, eg the end of the cold war in the 1990s and the end of the Apartheid regime in South Africa in 1994.

Furthermore, some would argue that there is reverse causality present, or that growth might generate inflation and not the inverse, Kocherlakota (1996) and Barro (2013). Hence, we use the Fixed Effects with Instrumental Variables (FE-IV) two-stage Least Squares estimator which provides asymptotically consistent and efficient estimates as $T \rightarrow \infty$, and it retains the time series consistency even if the instrument set is only predetermined, Arellano $(2003)^{2}$. For the choice of instruments we follow Barro (1995, 1998 and 2013) and make use of the first lag of inflation $\left(E\left(I N F L A T_{i t-1} v_{i t}=0\right)\right.$ as a baseline identifying instrument for contemporaneous inflation and it is expected that lagged inflation positively influences contemporaneous inflation.

We therefore estimate dynamic growth equations with different pooled

\footnotetext{
${ }^{2}$ In addition, Bond (2002) argues that GMM-type estimators are not an alternative under $T>N$ for the overfitting problem.
} 
estimators (the FE and FE-IV estimators), so that different econometric issues are dealt with and more reliable estimates provided ${ }^{3}$. The one-way FE estimated dynamic equation is as follows,

$$
\begin{aligned}
\text { RROW }_{i t}= & \alpha_{i}+\beta I N F L A T_{i t}+\gamma I N V_{i t}+\delta E D U C_{i t}+\epsilon G O V_{i t} \\
& +\varepsilon O P E N_{i t}+\zeta M 2_{i t}+\eta P O L_{i t}+\theta G R O W_{i t-1}+v_{i t}
\end{aligned}
$$

where GROW are the growth rates of the per capita GDPs, INFLAT are the inflation rates, $I N V$ is the share of gross fixed capital formation to GDP, $E D U C$ is the number of teachers per 100 pupils in secondary education, $G O V$ is the share of final government consumption to GDP, OPEN is a measure of economic openness, $M 2$ is the share of the liquid liabilities to GDP and $P O L$ is the political regime variable which proxies for democracy.

\subsection{Results and Discussion}

In Tables Two and Three we report the dynamic estimates of INFLAT on GROW using the one- and two-way FE estimator respectively. All INFLAT estimates are negative and statistically significant against GROW, which suggest that inflation is detrimental to economic growth, ie higher inflation rates contribute to distort the pace of overall economic activity in the community by increased macroeconomic uncertainty. For instance, the dynamic inflation estimates in columns (1), Tables Two and Three, indicate that an increase by 1 percentage point in the inflation rate leads to a decline by .15 percentage points in the annual growth rate. Moreover, in columns six, both tables, we report the Bruno-corrected estimates using the complete specification and they are in line with the ones reported in columns five, ie the Nickell bias is not of a significant size in regressions five. All in all, the Mundell-Tobin effect in the community is offset by the macroeconomic uncertainty originating from higher rates of inflation, Fischer (1993).

The canonical variable investment $I N V$, or capital accumulation, presents positive and mostly significant effects on $G R O W$, Bond, Leblebicioğlu and Schiantarelli (2010). On the other hand, the proxy EDUC for education does not present significant estimates against growth. This non-result of

\footnotetext{
${ }^{3}$ For a more thorough discussion about panel time-series analysis in general, see Smith and Fuertes (2010) or Lee, Pesaran and Smith (1998) for a treatment more applied to growth analysis.
} 
education is expected since the growth literature, for all sorts of reasonseg measurement error - has not been able to find conclusive evidence for the role of education on economic growth, Benhabib and Spiegel (1994) and Krueger and Lindahl (2001). Furthermore, although we have thirty years of data, some might argue that education only plays a role on growth in the very long run, Becker, Hornung and Woessmann (2011).

In addition, it can be argued that growth in the SADC is still based on physical capital instead of human capital accumulation, ie Galor (2005) argues that the first stage of the industrial revolution taking place in Britain in the $18^{\text {th }}$ century was mostly based on physical capital and not necessarily on formal human capital accumulation. It is therefore plausible to assume, as predicted by unified growth theory, that the SADC is going through the same sort of developmental process that more mature societies have already gone through, which explains why human capital is still not playing its expected role on growth in the community.

About the other control variables, the proxy for government consumption presents negative and mostly significant estimates on growth, which confirms that government consumption tends to be detrimental to economic activity because of particular inefficiencies associated with government spending and also perverse economic incentives associated with government activities, Barro (1991). The variable proxying for trade openness presents positive but not wholly significant estimates at this stage.

Furthermore, the liquid liabilities, $M 2$, perhaps because of informational asymmetries and lack of experience by smaller entrepreneurs in terms of how to make better use of finance, present negative and mostly significant estimates on growth, Foster and Székely (2008). In addition, the variable for democracy is positive, but not entirely significant. Finally, the $\mathrm{F}^{*}$ tests indicate that there is evidence of country fixed effects. 
Table 2: One-way Fixed Effects Estimates of Inflation on Economic Growth, 1980-2009.

\begin{tabular}{lrrrrrr}
\hline \hline GROW & FE $(1)$ & FE $(2)$ & FE $(3)$ & FE $(4)$ & \multicolumn{1}{c}{ FE (5) } & LSDVC (6) \\
\hline INFLAT & $-1.54(-4.48)$ & $-1.83(-6.52)$ & $-2.08(-6.46)$ & $-2.80(-4.90)$ & $-2.97(-5.21)$ & -2.92 \\
INV & $1.44(2.93)$ & $1.58(3.89)$ & $1.05(2.58)$ & $.607(1.39)$ & $.561(1.40)$ & .563 \\
EDUC & $-.588(-0.25)$ & $-1.76(-0.78)$ & $-2.51(-1.24)$ & $-.851(-0.43)$ & $-2.49(-1.05)$ & -2.58 \\
GOV & & $-3.53(-2.60)$ & $-3.42(-2.48)$ & $-2.59(-2.24)$ & $-2.71(-2.30)$ & -2.62 \\
OPEN & & & $2.71(2.14)$ & $2.30(1.75)$ & $1.85(1.46)$ & 1.84 \\
M2 & & & & $-1.65(-2.17)$ & $-1.48(-1.93)$ & -1.41 \\
POL & & & & & $.654(1.95)$ & .694 \\
GROW 1 & $.262(3.09)$ & $.238(2.68)$ & $.215(2.44)$ & $.121(1.32)$ & $.093(0.93)$ & \\
F test & 18.76 & 211.40 & 67.53 & 57.72 & 57.31 & \\
F $^{*}$ test $(\mathrm{p})$ & $1.63(0.06)$ & $2.66(0.00)$ & $2.48(0.00)$ & $4.00(0.00)$ & $3.68(0.00)$ & \\
$\mathrm{R}^{2}$ & 0.24 & 0.14 & 0.22 & 0.15 & 0.15 & \\
\hline \hline
\end{tabular}

T-ratios in parentheses. Number of observations: $N T=450$. The estimated equation is $G R O W_{i t}=\alpha_{i}+\beta I N F L A T_{i t}+\gamma I N V_{i t}+\delta E D U C_{i t}+\epsilon G O V_{i t}+$ $\varepsilon O P E N_{i t}+\zeta M 2_{i t}+\eta P O L_{i t}+\theta G R O W_{i t-1}+v_{i t}$, where $G R O W$ is the growth rate of the real GDP per capita, INFLAT is the inflation rate, $I N V$ is the gross fixed capital formation ratio to GDP, $E D U C$ is the number of teachers per 100 pupils, $G O V$ is the government's consumption share to GDP, $O P E N$ is a measure of economic openness, $M 2$ is the liquid liabilities ratio to GDP and $P O L$ is a proxy for political regime characteristics. FE is the one-way Fixed Effects estimator and the LSDVC are the Bruno-corrected estimates. 
Table 3: Two-way Fixed Effects Estimates of Inflation on Economic Growth, 1980-2009.

\begin{tabular}{|c|c|c|c|c|c|c|}
\hline GROW & $\mathrm{FE}(1)$ & $\mathrm{FE}(2)$ & $\mathrm{FE}(3)$ & $\mathrm{FE}(4)$ & $\mathrm{FE}(5)$ & $\operatorname{LSDVC}(6)$ \\
\hline INFLAT & $-1.57(-5.33)$ & $-1.77(-4.56)$ & $-1.91(-4.60)$ & $-2.52(-4.02)$ & $-2.73(-4.46)$ & -2.69 \\
\hline INV & $1.80(4.17)$ & $1.89(5.04)$ & $1.58(3.16)$ & $1.24(2.55)$ & $1.13(2.28)$ & 1.13 \\
\hline EDUC & $-2.10(-0.91)$ & $-2.58(-1.07)$ & $-2.67(-1.16)$ & $-.875(-0.35)$ & $-2.37(-0.85)$ & -2.53 \\
\hline GOV & & $-2.47(-1.74)$ & $-2.54(-1.79)$ & $-1.85(-1.53)$ & $-2.09(-1.60)$ & -2.00 \\
\hline OPEN & & & $1.57(1.16)$ & $.786(0.47)$ & $.649(0.41)$ & .671 \\
\hline M2 & & & & $-1.89(-2.01)$ & $-1.53(-1.50)$ & -1.48 \\
\hline POL & & & & & $.816(1.58)$ & .835 \\
\hline $\mathrm{GROW}_{-1}$ & $.194(2.39)$ & $.184(2.12)$ & $.176(2.05)$ & $.080(0.92)$ & $.049(.093)$ & .087 \\
\hline F test & 4.58 & 4.73 & 4.67 & 3.88 & 4.06 & \\
\hline $\mathrm{F}^{*}$ test $(\mathrm{p})$ & $1.99(0.01)$ & $2.51(0.00)$ & $2.31(0.00)$ & $4.15(0.00)$ & $3.99(0.00)$ & \\
\hline $\mathrm{R}^{2}$ & 0.32 & 0.25 & 0.30 & 0.20 & 0.21 & \\
\hline
\end{tabular}

T-ratios in parentheses. Number of observations: $N T=450$. The estimated equation is $G R O W_{i t}=\alpha_{i}+\vartheta_{t}+\beta I N F L A T_{i t}+\gamma I N V_{i t}+\delta E D U C_{i t}+\epsilon G O V_{i t}+$ $\varepsilon O P E N_{i t}+\zeta M 2_{i t}+\eta P O L_{i t}+\theta G R O W_{i t-1}+v_{i t}$, where $G R O W$ is the growth rate of the real GDP per capita, INFLAT is the inflation rate, $I N V$ is the gross fixed capital formation ratio to GDP, $E D U C$ is the number of teachers per 100 pupils, $G O V$ is the government's consumption share to GDP, $O P E N$ is a measure of economic openness, $M 2$ is the liquid liabilities ratio to GDP and $P O L$ is a proxy for political regime characteristics. FE is the two-way Fixed Effects estimator and the LSDVC are the Bruno-corrected estimates.

In Table Four we report the dynamic estimates of INFLAT on GROW using the FE-IV estimator which accounts for economic endogeneity. All INFLAT estimates - instrumented with lagged inflation - are negative and mostly statistically significant, Barro (1998). These instrumented dynamic inflation estimates confirm the results reported above, indicating that higher inflation rates are detrimental to economic growth in the SADC. For instance, using specification in column (3), an increase by 1 percentage point in the inflation rate leads to a decline by .15 percentage points in the annual growth rate.

About the controls, the variable investment is positive and mostly significant, lending credence to the Solovian prediction of the role of capital accumulation in growth, Bond, Leblebicioğlu and Schiantarelli (2010). Education, once again, does not present clear-cut or significant estimates, 
Krueger and Lindahl (2001). Furthermore, government consumption confirms its detrimental role on economic activity by distortions coming from government expenditure, Barro (1991), and trade openness confirms now its predicted positive role on economic growth as well (by an increase in flows of goods, people and knowledge, Wacziarg and Welch 2008). The latter is in accordance to one of SADC's aims which is about increasing trade integration in the community.

In addition, the financial development variable $M 2$ keeps its negative and significant estimates against growth, suggesting the existence of informational asymmetries in terms of access to short-term finance by small entrepreneurs, Foster and Székely (2008), and democracy presents a positive and significant estimate on economic growth (via better constraints on the executive that tend to improve governance, Papaioannou and Siourounis 2008). Needless to say that the latter bodes well with the objectives of the SADC as well, ie democracy and economic growth.

Moreover, the $\mathrm{F}^{*}$ test indicates, for most of the time, the presence of regional fixed effects, and in the first-stage regressions the identifying instrument for inflation, lagged inflation, is positive and statistically significant and the $\mathrm{F}$ test for overall significance indicates that we can reject the null as well, which minimise the issue of weak instruments ${ }^{4}$.

\footnotetext{
${ }^{4}$ We have run regressions with an alternative variable for openness, economc globalisation provided by Dreher (2006), and the results are robust to the ones reported. In addition, in the FE-IV regressions we tried with deeper lags of inflation and the results are robust as well. Furthermore, we have run regressions using the Mean Group estimator, Pesaran and Smith (1995), and the results are in line with the ones reported above. Available on request.
} 
Table 4: FE-IV Estimates of Inflation on Economic Growth, 1980-2009.

\begin{tabular}{lrrrrr}
\hline \hline GROW & FE-IV $(1)$ & \multicolumn{1}{c}{ FE-IV $(2)$} & FE-IV $(3)$ & \multicolumn{1}{c}{ FE-IV $(4)$} & \multicolumn{1}{c}{ FE-IV (5) } \\
\hline INFLAT & $-1.03(-1.58)$ & $-1.27(-1.94)$ & $-1.54(-2.30)$ & $-3.22(-4.15)$ & $-3.55(-4.54)$ \\
INV & $1.51(2.48)$ & $1.64(2.75)$ & $1.15(1.83)$ & $.507(0.75)$ & $.416(0.61)$ \\
EDUC & $-.683(-0.31)$ & $-1.79(-0.81)$ & $-2.49(-1.13)$ & $-.808(-0.38)$ & $-2.52(-1.12)$ \\
GOV & & $-3.33(-3.54)$ & $-3.25(-3.49)$ & $-2.60(-2.85)$ & $-2.73(-2.98)$ \\
OPEN & & & $2.49(2.52)$ & $2.38(2.24)$ & $1.94(1.82)$ \\
M2 & & & & $-1.68(-2.73)$ & $-1.51(-2.40)$ \\
POL & & & & & $.690(2.03)$ \\
GROW -1 & $.279(5.35)$ & $.258(4.96)$ & $.235(4.44)$ & $.107(1.92)$ & $.072(1.25)$ \\
F* test (p) & $1.51(0.10)$ & $2.37(0.00)$ & $2.13(0.00)$ & $3.99(0.00)$ & $3.72(0.00)$ \\
$\mathrm{R}^{2}$ & 0.25 & 0.14 & 0.22 & 0.15 & 0.14 \\
IV & $.770(19.18)$ & $.759(18.96)$ & $.744(18.45)$ & $.661(17.43)$ & $.656(16.80)$ \\
F test & 120.77 & 99.66 & 18.45 & 64.38 & 54.68 \\
\hline \hline
\end{tabular}

T-ratios in parentheses. Number of observations: $N T=450$. The estimated equation is $G R O W_{i t}=\alpha_{i}+\beta I N F L A T_{i t}+\gamma I N V_{i t}+\delta E D U C_{i t}+\epsilon G O V_{i t}+$ $\varepsilon O P E N_{i t}+\zeta M 2_{i t}+\eta P O L_{i t}+\theta G R O W_{i t-1}+v_{i t}$, where $G R O W$ is the growth rate of the real GDP per capita, INFLAT is the inflation rate, $I N V$ is the gross fixed capital formation ratio to GDP, $E D U C$ is the number of teachers per 100 pupils, $G O V$ is the government's consumption share to GDP, $O P E N$ is a measure of economic openness, $M 2$ is the liquid liabilities ratio to GDP and $P O L$ is a proxy for political regime characteristics. The identifying instrument is the first lag of inflation. FE-IV is the Fixed Effects with Instrumental Variables estimator.

In a nutshell, the estimates reported above indicate that the inflation rates robustly presented detrimental effects to economic growth in those SADC countries between 1980 and 2009. To say the least, low inflation rates are a necessary precondition for economic growth in the community, Fischer (1993), and Sirimaneetham and Temple (2009). Moreover, Seleteng, Bittencourt and van Eyden (2013) suggest that inflation rates above 18 percent become detrimental to growth in the community. Taking into consideration the heterogeneity of the sample - eg with Mozambique presenting high inflation (around 50 percent in the 1980s) and with Mauritius with single digits since the 1980s, and also the nature of panel estimators - inflation in the SADC offset the prospective Mundell-Tobin effect by an increase in macroeconomic uncertainty which leads to reduction, in the much needed, 
economic activity. All in all, differently from Bullard and Keating (1995) and Rapach (2003) who report that inflation can play a positive role in low-inflation industrialised countries, we are unable to find evidence for the Mundell-Tobin effect in the community.

The control variables also provide some interesting results. Firstly, investment presents positive and mostly significant estimates, which suggest that physical capital accumulation plays a role on growth in the community. Secondly, apart from the fact that physical capital seems to play a more important role than human capital in the community, perhaps $M 2$ is picking up the importance of a certain degree of education in order to make good use of short-run finance, so that those resources could be used, usually by smaller entrepreneurs, to fund productive activities. All in all, the results of investment and education seem to be in accordance with the unified growth theory prediction which suggests that the first stage of processes of industrial development (the post-Malthusian regime) is based on physical, instead of human, capital accumulation, Galor (2005).

In addition, the proxy for government size, which is negative and mostly significant, is suggestive of the importance of a better allocation of government expenditure so that government consumption can be better channelled to more productive activities, eg R\&D and infrastructure. Finally, the variables openness and democracy present positive and mostly significant estimates against growth, and these estimates are in line with what is expected, Wacziarg and Welch (2008) and Papaioannou and Siourounis (2008) and also bode well with the objectives of the SADC, ie of achieving regional integration and democracy combined with economic prosperity.

\section{Concluding Observations}

Using a dataset covering the period between 1980 and 2009, in this paper we investigated the role of inflation rates in determining economic growth in a panel of sub-Saharan African countries that are all members of the SADC. The results, based on panel time-series analysis, suggest that inflation was detrimental to growth in the community.

More specifically, inflation proved to be a robust macroeconomic determinant of growth, which highlights its central role in determining economic activity in the community. Moreover, these detrimental effects to economic 
activity outweighed the Mundell-Tobin effect (or alternatively speaking, inflation has increased macroeconomic uncertainty or induced agents to shift to less productive activities).

The quality of the evidence presented is, to a certain extent, boosted because we avoid the averages and take advantage of panel time-series analysis which deals with important empirical issues, such as heterogeneity bias in dynamic panels, and statistical and economic endogeneity in relatively thin panels. Essentially, this analysis is important because it allows us to specifically study the SADC, instead of treating the community either as a dummy or as an outlier to be removed from the sample. Therefore, the analysis - on an enduring and rich subject that offers different directions in terms of causality - represents a step forward in terms of achieving insightful estimates and in improving our knowledge on the subject in sub-Saharan Africa.

About future work, the issue of spatial dependence and inflationary spillovers (plausibly coming from the largest economy in the community, South Africa) is an interesting, and of practical importance, subject that deserves some attention and could complement the present study. Moreover, in terms of policy, given that South Africa has presented low inflation for most of the period and also for its relative privileged position in terms of institutional quality and development, the use of the South African Rand as an anchor is a possibility for countries that - for not having the necessary institutional structure in place - end up from time to time with inflation rates above the threshold proposed by Seleteng, Bittencourt and van Eyden (2013).

To conclude, the SADC experience is informative because it exemplifies (once again) the importance of a variable that requires particular economic institutions, such as independent and well-staffed central banks conducting sound monetary policy and credible fiscal authorities, to be in place. Moreover, in times of a crisis affecting a number of countries worldwide, it is important to keep in mind that (low) inflation in the SADC is a precondition for economic activity and also that high inflation affects, in one way or another, mostly the welfare of the poor. Therefore, the importance of independent economic institutions in providing the necessary conditions for growth and the lessons of past historical macroeconomic mismanagement episodes and their effects on economic activity must be learned and well 
understood, and also kept in the minds of policy makers and other stakeholders, so that the mistakes of the past are not repeated again.

\section{References}

[1] Acemoglu, Daron, Simon Johnson, Pablo Querubín, and James A. Robinson. 2008. When Does Policy Reform Work? The Case of Central Bank Independence. Brookings Papers on Economic Activity 1:353-418.

[2] Arellano, M. 2003. Panel data econometrics. Oxford University Press: Advanced texts in Econometrics.

[3] Barro, Robert J. 2013. Inflation and Economic Growth. Annals of Economics and Finance 14(1): 85-109.

[4] Barro, Robert J. 1998. Determinants of Economic Growth: A Crosscountry Empirical Study. The MIT Press.

[5] Barro, Robert J. 1995. Inflation and Economic Growth. In NBER Working Paper Series.

[6] Barro, Robert J. 1991. Economic Growth in a Cross Section of Countries. Quarterly Journal of Economics 106 (2):407-443.

[7] Becker, Sascha, E. Hornung, and L. Woessmann. 2011. Education and catch-up in the industrial revolution. American Economic Journal: Macroeconomics 3 (July):92-126.

[8] Benhabib, Jess, and Mark Spiegel. 1994. The role of human capital in economic development: evidence from aggregate cross-country data. Journal of Monetary Economics, 34: 143-173.

[9] Berger, Daniel, Alejandro Corvalan, William Easterly, and Shanker Satyanath. 2013. Do superpower interventions have short and long term consequences for democracy? Journal of Comparative Economics 41:2234.

[10] Besley, Timothy J. and Torsten Persson. 2008. The Incidence of Civil War: Theory and Evidence. NBER Working Paper No. w14585. 
[11] Bittencourt, Manoel. 2012. Inflation and economic growth in Latin America: some panel time-series evidence. Economic Modelling 29:333340.

[12] Bond, Stephen R. 2002. Dynamic Panel Data Models: A Guide to Micro Data Methods and Practice. Portuguese Economic Journal 1 (2):141-62.

[13] Bond, Stephen, Asli Leblebicioğlu, and Fabio Schiantarelli. 2010. Capital Accumulation and Growth: a New Look at the Empirical Evidence. Journal of Applied Econometrics 25:1073-1099.

[14] Bruno, Giovanni. 2005. Approximating the bias of the LSDV estimator for dynamic unbalanced panel data models. Economic Letters 87:361366 .

[15] Bruno, Michael, and William Easterly. 1998. Inflation crises and longrun growth. Journal of Monetary Economics 41:3-26.

[16] Bullard, James, and John W. Keating. 1995. The long-run relationship between inflation and output in postwar economies. Journal of Monetary Economics 36:477-496.

[17] Bun, M.J.G. and Kiviet, J.F. 2003. On the diminishing returns of higher order terms in asymptotic expansion of bias. Economics Letters 79:145152 .

[18] Clark, Todd E. 1997. Cross-country evidence on long-run growth and inflation. Economic Inquiry XXXV:70-81.

[19] Dreher, Axel (2006). "Does Globalization Affect Growth? Empirical Evidence from a new Index." Applied Economics 38 10: 1091-1110.

[20] Durlauf, S. N., Johnson, P. A., and Temple, J. R. W. 2005. Growth econometrics. In P. Aghion and S. N. Durlauf (eds.) Handbook of Economic Growth, Volume 1A, North-Holland: Amsterdam.

[21] Fischer, Stanley. 2005. IMF Essays from a Time of Crisis, The MIT Press: Cambridge, Massachusetts and London, England.

[22] Fischer, Stanley. 1993. The role of macroeconomic factors in growth. Journal of Monetary Economics 32:485-512. 
[23] Foster, James E., and Miguel Székely. 2008. Is economic growth good for the poor? Tracking low incomes using general means. International Economic Review 49 (4):1143-1172.

[24] Galor, Oded. 2005. From Stagnation to Growth: Unified Growth Theory. In Handbook of Economic Growth, edited by P. Aghion and S. Durlauf. Amsterdam: Elsevier North-Holland.

[25] Ghosh, Atish, and Steven Phillips. 1998. Warning: Inflation May Be Harmful to Your Growth. IMF Staff Papers 45 (4):672-710.

[26] Gregorio, José De. 1993. Inflation, taxation, and long-run growth. Journal of Monetary Economics 31:271-298.

[27] Judson, Ruth, and Ann Owen. 1999. Estimating dynamic panel data models: a guide for macroeconomists. Economics Letters 65:9-15.

[28] Khan, Mohsin S., and Abdelhak S. Senhadji. 2001. Threshold Effects in the Relationship Between Inflation and Growth. IMF Staff Papers $48(1): 1-21$.

[29] Kocherlakota, Narayana. 1996. Inflation and growth - commentary. Review, Federal Reserve Bank of St. Louis May:170-172.

[30] Krueger, Alan, and Mikael Lindahl. 2001. Education for Growth: Why and for Whom? Journal of Economic Literature 39:4.

[31] Lee, Kevin, H. Pesaran, and R.P. Smith. 1998. Growth empirics: a panel data approach - a comment. Quarterly Journal of Economics 113:319323.

[32] Levine, Ross. 2005. Finance and Growth: Theory and Evidence. In Handbook of Economic Growth, edited by P. Aghion and S. Durlauf. Amsterdam: North-Holland.

[33] Mankiw, N. Gregory, David Romer, and David Weil. 1992. A Contribution to the Empirics of Economic Growth. The Quarterly Journal of Economics, 107:2.

[34] Papaioannou, Elias and Gregorios Siourounis. 2008. Democratisation and Growth. Economic Journal, 118:1520-1551. 
[35] Pesaran, M. Hashem, and Ron Smith. 1995. Estimating Long-Run Relationships from Dynamic Heterogeneous Panels. Journal of Econometrics 68 (1):79-113.

[36] Phillips, P. and H. R. Moon. 1999. Linear Regression Limit Theory for Nonstationary Panel Data. Econometrica 67 (5):1057-1112.

[37] Pinkovskiy, Maxim, and Xavier Sala-i-Martin. 2014. Africa is on Time. Journal of Economic Growth 19:311-338.

[38] Rapach, David. 2003. International Evidence on the Long-Run Impact of Inflation. Journal of Money, Credit, and Banking 35 (1):23-48.

[39] Sarel, Michael. 1996. Nonlinear Effects of Inflation on Economic Growth. IMF Staff Papers 43 (1):199-215.

[40] Seleteng, Monaheng, Manoel Bittencourt, and Reneé van Eyden. 2013. Non-linearities in inflation-growth nexus in the SADC region: A panel smooth transition regression approach. Economic Modelling 30:149-156.

[41] Sirimaneetham, Vatcharin, and Jonathan R. W. Temple. 2009. Macroeconomic Stability and the Distribution of Growth Rates. World Bank Economic Review 23 (3):443-479.

[42] Smith, Ron, and Ana-Maria Fuertes. 2010. Panel Time-Series. In London: Centre for Microdata Methods and Practice. Institute for Fiscal Studies.

[43] Solow, Robert (1956). "A Contribution to the Theory of Economic Growth". Quarterly Journal of Economics 70: 65-94.

[44] Wacziarg, Romain, and Karen Welch. 2008. Trade liberalisation and growth: new evidence. World Bank Economic Review, 22 (2):187-231. 